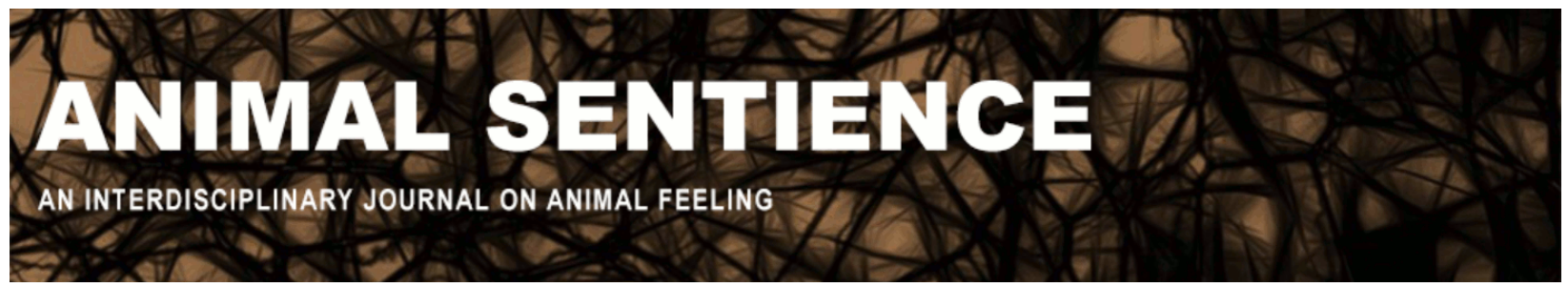

Freeman, Carrie P. (2019) Taking exception to human exceptionalism. Animal Sentience 23(32)

DOI: $10.51291 / 2377-7478.1412$

Date of submission: 2019-02-09

Date of acceptance: 2019-02-18 (c) 


\title{
Taking exception to human exceptionalism
}

\author{
Commentary on Chapman \& Huffman on Human Difference
}

\author{
Carrie P. Freeman \\ Department of Communication \\ Georgia State University
}

\begin{abstract}
Chapman \& Huffman refute common claims used to justify human species distinctions, and they critique the animal cruelty that has resulted from this privileged status. I raise related questions for further study of the roots of human exceptionalism and about whether aspiring to be more like our fellow animals might be part of the solution.
\end{abstract}

Carrie P. Freeman writes about
environmental communication, critical
animal studies, activist communication, and
media ethics. In 2014, she published the
vegan advocacy book Framing Farming:
Communication Strategies for Animal Rights.
She co-authors the style guide for responsible
representations of animals. Website

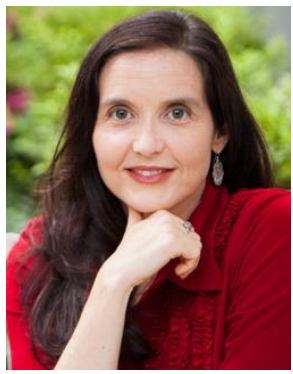

It is gratifying to see scientists addressing the root problem of environmental and animal exploitation - human privilege. In this important effort, Chapman \& Huffman (2018) (C \& H) summarize the arguments that humans have used to justify human superiority, and they refute them as grounds for human exceptionalism. (Other humanities and social science scholars who have explored this are Abram, 1997; Derrida, 1995; Freeman, 2010; Ingold, 1988; and Lawrence, 1995.) The authors then briefly outline and critique some of the ways human society is destructive and cruel to other animals due to the belief that humans are the species who matter most.

In their abstract, $\mathrm{C} \& \mathrm{H}$ raise the question of whether humans are using this exalted sense of self to justify animal cruelty. Even a cursory look at our society and history answers this question emphatically in the affirmative. In most cases, cruelty is not the aim of human exceptionalism but a predictable side effect when human cultures give ourselves the moral and legal permission to use nonhuman beings as means to our ends. Human moral superiority as a justification for discriminating against other animals is what animal ethics philosophers have been trying to refute. In defense of animal rights and liberation, Regan (1983) and Singer (1990) rely on animal sentience and consciousness to justify valuing fellow animals equitably as subjects rather than objects.

Instead of asking what distinguishes humans from other animals, philosopher Midgley (2004) recommends we focus more constructively on identifying the best traits of human nature, including those we may share with many other species. All movements for justice would benefit from understanding how humans can, as C \& H suggest, look at differences horizontally and neutrally rather than ranking them in a vertical hierarchy. A related question for psychologists is whether humans can have a more humble self-perception in relation to the rest of the animal 
kingdom. Terror management theory suggests one possible reason humans deny their animality in favor of exceptionalism: a desire to deny being yet another mortal creature of nature (Marino \& Mountain, 2015).

Another important opportunity for self-exploration raised in $\mathrm{C} \& \mathrm{H}^{\prime} \mathrm{s}$ article is the suggestion "to acknowledge how much we resemble them and how much we have to learn from them," aspiring to achieve some of their biological and cultural traits instead of just the ones we privilege in ourselves (intelligence; tool design and use; technological power; writing and mass communication; art and storytelling; mass capacity to build, alter, and/or destroy; and ironically, ethics). The traits we learn from other animals might include sustainability, mindfulness, insight, patience, cooperation, teamwork, community, listening and perception, diligence, and perhaps most necessary of all, humility.

\section{References}

Abram, D. (1997). The Spell of the Sensuous: Perception and Language in a More-than-Human World. New York: Vintage Books.

Chapman, C. \& Huffman, M. (2018). Why do want to think humans are different? Animal Sentience 23(1).

Derrida, J. (1995). Eating well, or the calculation of the subject. In P. Conner \& A. Ronell (Ed.), Points ... Interviews, 1974-1994, Jacques Derrida, 255-287. Stanford, CA: Stanford University Press.

Freeman, C. P. (2010). Embracing humanimality: Deconstructing the human/animal dichotomy. In G. Goodale \& J. E. Black (Ed.), Arguments about Animal Ethics, 11-30. Lanham, MD: Lexington Books.

Ingold, T. (1988). Introduction. In T. Ingold (Ed.), What Is an Animal? 1-16. London: Unwin Hyman.

Lawrence, E. A. (1995). Cultural perceptions of differences between people and animals: A key to understanding human-animal relationships. Journal of American Culture 18(3): 75-82.

Marino, L. \& Mountain, M. (2015). Denial of death and the relationship between humans and other animals. Anthrozoos 28(1): 5-21.

Midgley, M. (2004). The lure of the simple distinction. In A. Linzey \& P. B. Clarke (Eds.), Animal Rights: A Historical Anthology, 48-50. New York: Columbia University Press.

Regan, T. (1983). The Case for Animal Rights. Berkeley, CA: University of California Press. Singer, P. (1990). Animal Liberation (2nd ed.). New York: Random House. 